pressure burst is fairly well understood by those who have to deal with these very dangerous phenomena. One short paper deals with "Rock Bursts Prevention", but it would seem that the author has not really succeeded in preventing these serious accidents. The volume may be strongly recommended to all interested in deep-level mining problems.

\section{Missions in New Spain}

INTEREST inspired by the archæology of Mexico and Central America is apt to divert attention from the study of the Indians themselves who lived in these regions, and the effect on them of the clash of cultures which arose out of the Spanish conquest, both at the time and in their subsequent history. It is, in fact, only comparatively recently that it has been realised that the customs and beliefs of the Indian of to-day present an unrivalled field for the study of syncrisis in culture and religion. The possibilities of such study are suggested, for example, by a recent publication of the Institut d'Ethnologie of Paris, "La Conquete spirituelle du Mexique", by M. Robert Ricard (Trav. et Mem., 20), in which it is remarked that the failure of the Church to establish a native priesthood as part of the campaign of Christianisation has never ceased to affect the course of history in the country down to this day by segregating the native population, even though the Spaniards were never affected by the colour-line in the accepted sense. M. Ricard's able study of the Catholic missions in Mexico from 1523-4 until 1572, that is, from the first arrival of the mendicant friars, after the conquest of Cortez, down to the arrival of the Jesuits, is based on a careful study of early records. It has, as one side of the picture, the culture of the Indians whom the friars sought to convert, as seen through the eyes of writers such as Sahagun, who recorded native customs for the instruction of those whose duties called them to the work. M. Ricard's researches have placed the early work of the Church in a more correct perspective than has hitherto been possible.

\section{Studies of American Social Areas}

THE thoroughness and detail with which American investigators carry out their inquiries is well exemplified in a series of bulletins recently published by Cornell University Agrisultural. Experiment Station, dealing with the social and economic characteristics of various counties in New York State. In one of these bulletins written by Mr. H. C. Hoffsommer and entitled "Relation of Cities and Larger Villages to Changes in Rural Trade and Social Areas in Wayne County, New York", it is explained that the villages with a population of 500 persons or less have suffered severely from the competition of the larger villages. The smaller villages, however, have maintained their status better socially than economically, and it is interesting to note that the average distance travelled is shortest for church attendance and greatest for the purchase of women's dresses. The data show that social life at present is carried on in relatively small areas. That it will always be so does not follow, and a trend towards the uniting of small social areas into larger ones is evident. But the expansion of the social areas has been much less marked than that of commercial areas. This leads to the conclusion that although churches, schools, and other social and educational agencies may unite for better and more effective work, the areas which they can effectively serve will remain relatively small as compared to those of the more specialised economic services.

\section{Showers of Fish}

For more than two thousand years, occasional showers of fish are said to have occurred in various parts of the world, but especially in India, in stormy, or at least showery, weather. In the Journal of the Asiatic Society of Bengal (29, No. 1; 1933), Dr. Sunder Lal Hora discusses Indian examples of the phenomenon, and gives references to papers dealing with these, some of which appeared more than a century ago. He also considers various explanations that have been advanced, and obviously inclines to the one according to which the fish in such a shower are sucked up from a pond or river by a waterspout and are deposited on the ground when the waterspout collapses. There is on the face of it no obvious objection to the theory, for the waterspout does sometimes occur in India, when the funnel-shaped tornado cloud that occasionally depends from a cumulo-nimbus cloud passes over any inland sheet of water. Dr. Hora's paper is followed by one by $\mathrm{S}$. N. Sen, who for a number of years was on the staff of the Meteorological Office, London. Sen examines the meteorological conditions over India at the time when a recent shower of fishes was reported from the Muzaffarpur District, Bihar, on July 10, 1933, and finds that they were such as would frequently give rise to very disturbed cyclonic weather and violent thunderstorms, and that some notably heavy rains occurred on the day in question. The theory favoured by Dr. Hora remains, however, to be proved. One is tempted to think that what has generally been observed has been heavy rain and afterwards many small fish on the ground, but not a shower of fish, and that the minds of native observers of the two separate phenomena have been affected by mythological beliefs that seemed to offer an explanation of what had been observed. Dr. Hora refers to such a myth (a Hindu myth) connected with the raingod Indra, according to which the waterspout is the trunk of one of Indra's elephants (the rain clouds are believed to be his elephants), who are engaged in sucking water up from the underworld during a storm in which the funnel cloud appears

\section{Forest Fires}

During last year's drought, fires caused considerable damage in plantations in Great Britain; also to the beautiful heaths and commons which form so picturesque a feature of certain English counties. This year, apart from official statistics, the reports in the Press afford evidence that this fire damage 